13. Brooks, C. R. \& Bogni, F. Mater. Character. 38, 103-117 (1997) 14. Steele, A. et al. Lunar Planet. Sci. 28, 1369-1370 (1997).

15. Morrison, D. A. \& Clanton, U. S. Proc. Lunar Planet. Sci. Conf. 10, 1649-1663 (1979)

16. Newbury, D. E., Joy, D. C., Echlin, P., Fiori, C. E. \& Goldstein, J. I. in Advanced Scanning Electron Microscopy and X-Ray Microanalysis (Plenum, New York, 1986).

17. Kajander, E. O., Kuronen, I., Åkerman, K., Pelttari, A. \& Ciftçioglu, N. in Proc. Soc. Photo-Opt. Instrum. Eng. Vol. 3111 (ed. Hoover, R. B.) 420-428 (Int. Soc. Opt. Eng., Bellingham, WA 1997).

18. Ciftçioglu, N., Pelttari, A. \& Kajander, E. O. in Proc. Soc. PhotoOpt. Instrum. Eng. Vol. 3111 (ed. Hoover, R. B.) 429-435 (Int. Soc. Opt. Eng., Bellingham, WA 1997).

19. Kieft T. L. in Nonculturable Microorganisms in the Environment (eds Colwell, R. R. \& Grimes, D. J.) (Chapman and Hall, New York, in the press).

20. Romanek, C. S. et al. Nature 372, 655-657 (1994).

21. Valley, J. W. et al. Science 275, 1633-1638 (1997).

22. Gleason, J. D., Kring, D. A., Hill, D. H. \& Boynton, W. V. Geochim. Cosmochim. Acta 61, 3503-3512 (1997).

23. Hanzlik M., Winklhofer M. \& Petersen N. Earth Planet. Sci. Lett. 145, 125-134 (1996).

24. von Dobeneck T., Petersen N. \& Vali H. Geowiss. Uns. Zeit 1, 27-35 (1987).

25. Westall, E. in Astronomical and Biochemical Origins and the Search for Life in the Universe (eds Cosmovici, C.B., Bowyer, S. \& Werthimer, D.) 491-504 (Compositori Editrice, Bologna, 1997).

26. Westall F. Darmstädter Beiträge zur Naturges. 4, 29-43 (1994).

\section{Travelling waves in vole population dynamics}

Spatial self-organization patterns in population dynamics have been anticipated ${ }^{1-3}$, but demonstrating their existence requires sampling over long periods of time at a range of sites. Voles cause severe economic damage and are therefore extensively
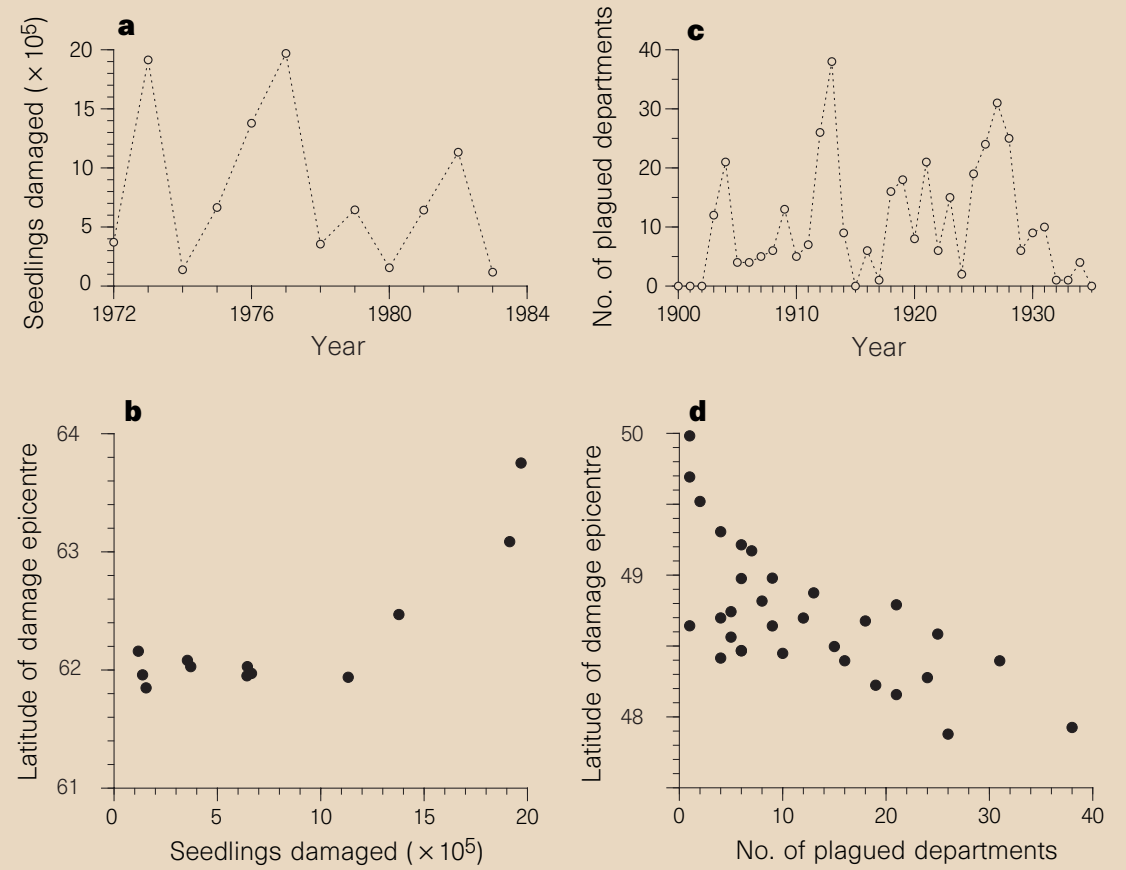

Figure 1 Extent and severity of vole damage. a, The number of seedlings destroyed by voles on study plots in young forest plantations in Finland ${ }^{5,6} . \mathbf{b}$, The dynamics are characterized by movement of the annual damage epicentre from south to north as total damage increases. c, Geographical extent of French ${ }^{4}$ vole plagues; and $\mathbf{d}$, annual epicentre of plagues plotted against the number of plagued departments. like those seen in the Scandinavian voles ${ }^{7}$. Again there was a correlation between the latitude of the annual location of the centre of mass and the geographical extent of the damage $(r=-0.67, P<0.001$; for the longitude $r=0.06)$. Accordingly, the French vole plagues spread from north to south, whereas in Finland they spread from south to north.

A variable is said to be spatially autocorrelated when it is possible to predict the values of this variable in one site from the known values at nearby sampling sites ${ }^{9}$. We performed autocorrelation analyses for irregularly spaced interval (Finland) or nominal scales (France) ${ }^{10}$.

For the Finnish data, we computed annual autocorrelation coefficients ${ }^{9-11}$ for the distance class of $200 \mathrm{~km}$ assuming binary links. We detected significant positive spatial autocorrelation in six of the twelve years. For the French data we computed annual spatial autocorrelations using binary weights and assuming a link between sites that were less than $120 \mathrm{~km}$ apart. We found a significant spatial autocorrelation present in the data in 14 of the 33 years. Both results indicate that spatial structure exists in these populations.

By identifying spatial autocorrelation in vole populations and an annually moving epicentre of vole plagues as a function of damage extent, we conclude that travelling waves, or pulses, in the dynamics of vole populations exist, a phenomenon predicted $^{1-3}$ by theoretical population ecology.

\section{Esa Ranta}

Department of Ecology and Systematics,

University of Helsinki,

PO Box 17,

FIN-00014 Helsinki,

Finland

e-mail:esa.ranta@helsinki.fi

\section{Veijo Kaitala}

Department of Biological and Environmental

Science,

University of Jyväskylä,

Box 35,

FIN-40351 Jyväskylä,

Finland

1. Hassell, M. P., Comins, H. N. \& May, R. M. Nature 353, 255-258 (1991).

2. Rohani, P. \& Miramontes, O. Proc. R. Soc. Lond. B 260, 335-342 (1995).

3. Bascompte, J. \& Sole, R. Trends Ecol. Evol. 10, 361-366 (1995).

4. Elton, C. Voles, Mice and Lemmings. Problems in Population Dynamics (Clarendon, Oxford, 1942).

5. Teivainen, T. Folia Forestalia 387, 1-23 (1979).

6. Teivainen, T. Metsäntutkimuslaitoksen Tiedonantoja 145, 1-12 (1984).

7. Hansson, L. \& Henttonen, H. Oecologia 67, 394-402 (1985).

8. Ranta, E., Kaitala, V., Lindström J. \& Lindén, H. Proc. R. Soc. Lond. B 262, 113-118 (1995).

9. Sokal, R. R. \& Oden, F. M. L. S. Biol. J. Linn. Soc. 10, 199-228 (1978)

10. Legendre, P. \& Fortin M.-J. Vegetatio 80, 107-138 (1989). 11. Moran, P. A. P. Biometrika 37, 17-23 (1950). 